\title{
Folding in Recreational Mathematics during the 17th-18th Centuries: Between Geometry and Entertainment
}

\author{
Michael Friedman \\ Excellence Cluster Bild Wissen Gestaltung, \\ Humboldt University \\ Sophienstraße 22a, 2. courtyard, \\ Berlin 10178, Germany \\ E-mail: michael.friedman@hu-berlin.de
}

\author{
Lisa Rougetet \\ Centre François Viète, \\ Université de Bretagne Occidentale \\ 20 Rue Duquesne, \\ Brest 29200, France \\ E-mail: lisa.rougetet@univ-brest.fr
}

\begin{abstract}
This article aims to present how paper-folding activities were integrated into recreational mathematics during the 17th and the 18th centuries. Recreational mathematics was conceived during these centuries as a way not only to pique one's curiosity, but also to communicate mathematical knowledge to the literate classes of the population. Starting with Leurechon's 1624 Récréation mathématique, which did not contain any exercise concerning paper folding, we show how two other traditions-Dürer's folded nets on the one hand and napkin folding on the other hand-prompted and influenced the integration of folding within subsequent books and manuscripts, especially those of Georg Philipp Harsdörffer and Daniel Schwenter. In Germany, but also to a lesser extent in France, folding was henceforth re-conceptualised within recreational mathematics as a way to transmit geometrical knowledge. Following Harsdörffer, the paper will claim that practising folding activities enabled the acquiring of a geometrical knowledge, which was haptic rather than symbolical or merely visual. This tactility reflects the Baconian conception of science and scientific experiment; and the paper will try to illuminate
\end{abstract}


how folding, by advancing practice and tactility via experiments, was representing these traditions and conceptions.

Keywords: 17 th-18th centuries, Baconian conception of science, mathematical practice, napkin folding, paper folding, recreational mathematics

\section{Introduction}

Recreational mathematics and physics is a literary and an editorial genre, which — starting in the 17 th century-encouraged readers to practise activities other than just reading: inviting them to practise the sciences in a playful form (Chabaud, 1994). Based sometimes on what might seem illusions and tricks, this genre challenged readers to understand what happened in such things. According to Singmaster (2008), Luca Pacioli's 1508 book De viribus quantitatis (On The Power OfNumbers) can be considered one of the first books in this genre, but the purpose-in line with the humanist movement at that time-was more to reveal the properties of numbers and to show that understanding them was possible in a tangible way through playful statements, rather than really amuse. Even if it was held in the archives of the University of Bologna and remained unpublished for over five hundred years, many problems can be found in later recreational mathematics books. ${ }^{1}$ But, as we will see, this new genre emerged in France with Jean Leurechon's Récréation mathématique in $1624,{ }^{2}$ a book having pedagogical origins (as Leurechon was a teacher), intended for the urban elite who could read French (Chabaud, 1994, p. 15). The book was quite a success and was reissued several times to reach new audiences. ${ }^{3}$ Initially, the general purpose of these recreational mathematics problems was to stimulate readers' curiosity via the inventive aspect of these problems and tricks, as well as to satisfy the desire for

1 For instance, Claude-Gaspard Bachet's Problèmes plaisants et délectables, published in 1612, is clearly inspired by the De viribus quantitatis: according to Heeffer (2004, p. 18), about one third of the problems can be traced back to Pacioli.

2 This does not mean that there were no books containing recreational problems before 1624 (Pacioli and Bachet are examples, but also Michel Coignet's compilation of recreational questions contained in Valentin Mennher's Arithmetique (1570), entitled Cent questions ingénieuses pour aiguiser et délécter l'entendement, in 1573), but the editorial genre clearly gained in importance during the 17th century, after the publication of Récréation mathématique.

3 This publication should be distinguished from Bachet's Problèmes plaisants et délectables, which was clearly intended for few intellectuals. For a more detailed research on the development of the recreational mathematics and physics genre in France in the 17th and 18th centuries, see Chabaud, 1994. For a more detailed research on the diffusion of Jesuit teaching in the late 16th and early 17th centuries, see Romano, 1995. 
knowledge, by giving pleasure to the reader. However, over the centuries, the role these books and games played changed considerably. In France, these "marginal mathematics" (Barbin, 2007, p. 22) have not had the same aims over time, as Évelyne Barbin notes:

The first recreational works date back to the 1620s, with Problemes plaisants et délectables sur les nombres by Claude Gaspard Bachet de Meziriac and Les Récréations mathématiques composées de plusieurs problèmes plaisants et facétieux by Henry von Etten, while the famous Jacques Ozanam's Récréations mathématiques et physiques were published in 1694. The aim of the ancient recreations was above all to "pique one's curiosity" whereas those who appeared at the end of the 19th century and the beginning of the 20th had three other purposes.

The first was to teach mathematics [...] The second was to circulate new mathematics $[\ldots]$ The third aim was to educate with sharing recent historical researches. (Barbin, 2007, p. 22)

Our study mainly deals with books of mathematical recreations of the 17th and 18 th centuries, those that aimed to "pique one's curiosity". We will focus on activities of paper folding developed in Germany and France. Choosing to focus only on one type of activity-paper folding-allows us to locate the sources of influence, on and of this activity, and to explicate more clearly what kind of mathematical knowledge might be transmitted through it. We limited our survey to this period in order to focus on the main books and manuscripts published at that time on recreational mathematics, and in order to examine how other, older traditions were integrated into this genre. As Barbin indicates, the purposes of the genre evolved in a different manner during the 19th and 20th centuries, a period which is beyond the scope of this paper. ${ }^{4}$

We assume that there are two traditions of the 17th and 18th centuries that prompted the emergence of paper folding in recreational mathematics: the first tradition is napkin folding, a leisure activity coming from Italy with Matthias Giegher and his book Li tre trattati, published in 1629; and a second tradition, a German one, whose influence was less strong: the construction of nets of folded polyhedra by Albrecht Dürer (1471-1528) and his followers, which originated in Nuremberg. ${ }^{5}$ We aim, therefore, to explain how folding activities

4 On how recreational mathematics and physics was accepted in France during the 19th century, see Lachapelle, 2015.

5 Obviously Dürer's folding nets are also the origin of another mathematical tradition, being the presentation of polyhedra via their nets. 
were integrated into recreational mathematics during the 17th and the 18th centuries. Indeed, the practice of folding, though being a marginal aspect in the recreational mathematics tradition during these centuries, represents-through the community of mathematicians that we will survey - an oscillation between two poles, that is, between the experimental Baconian conception of science, and the creation of wonders and amusements through games. But both aspects, as we will show, served to disseminate mathematical knowledge, which is neither symbolical nor necessarily visual, but rather haptic.

We start the article by explaining briefly the context of the emergence of Leurechon's Récréation mathématique in France, and the importance of the book for the development of the genre of recreational mathematics. We then make a detour to present the two traditions that transferred to recreational mathematics activities, namely napkin folding and folded nets of polyhedra. The two later sections give a detailed analysis of two major books of recreational mathematics in Germany, written and extended by Daniel Schwenter (in 1636) and Georg Philipp Harsdörffer (in 1652), respectively, The Erquickstunden. The two last sections analyse two important books in France, in which napkin and paper folding considerations can be found: L'escole parfaite des officiers de bouche (1662), intended for equerries responsible for cooking, and Jacques Ozanam's Récréations mathématiques et physiques, especially the posthumous 1723 and 1799 republications. We will see through these different works that both traditions of napkin folding and folded polyhedra were far less significant in France than in Germany in recreational mathematics books, and we will try to give some explanations of such differences in the conclusion.

\section{Récréation mathématique (1624)}

Récréation mathématique was published in 1624 in Pont-à-Mousson under the name of the Jesuit Jean Leurechon. ${ }^{6}$ It played an important role in the Jesuit community; in that period, it advocated mathematical instructions which included, besides arithmetic and geometry, cosmography, mechanics, optics

6 In fact, it is not really certain that Leurechon is the author of the book, since many characters took part in the publication: the dedication is from Henry van Etten, the book is registered in the libraries under the name Leurechon, and Jean Appier Hanzelet, engraver and printer at the University of Pont-à-Mousson, published it. Albrecht Heeffer (2004) surveys the authorship of the book, using the arms represented on the frontispiece (and the lack of any Jesuit symbol), and it seems highly probable that Jean Appier Hanzelet wrote the book. 
and military engineering. Consequently, sciences played a significant role in the pedagogical aspects that Jesuits wanted to present to the "urban elite" who could read French: a form of "urban theatre" [théâtre urbain] was used, in which sciences were "put on stage" (Chabaud, 1994, p. 18). Récréation mathématique invites the reader to take part in an entertaining practice which consists in showing the surprising power that sciences can provoke through illusory magical effects and tricks. The tricks are made to surprise the readers, enabling a display of intellectual superiority in relation to them.

Récréation mathématique is essential for the history of science and of mathematics, since it is considered as the first to emerge in the recreational mathematics editorial genre. This is the reason why details about the book are given here to provide to the readers the best understanding of the historical context. According to Heeffer, the book brings together two $16^{\text {th }}$-century traditions-mercantile arithmetic and natural magic-and creates two new ones-recreational mathematics and popular science. Copies of Récréation mathématique and the multiple republications (more than nine printings between 1628 and 1660, and over forty-three French books had the term "Récréations mathématiques" in their title between 1624 and 1790) helped the recreational mathematics genre develop and circulate in Europe. Section 4 of this article reveals how Daniel Schwenter was inspired by Récréation mathématique to develop his own Deliciae physico-mathematicae (1636). However, since Récréation mathématique does not present any folding exercises, Schwenter's considerations on paper folding are inspired not only by the then existing recreational mathematics' tradition, but also by the tradition of constructing polyhedra by folding nets, introduced by Dürer and his followers. In the following, a short detour into the two traditions ${ }^{7}$ that prompted the integration of paper folding into recreational mathematicsnapkin folding and folded polyhedra-is presented.

\footnotetext{
7 We aim to show in this article that these two traditions were indeed the main ones, though there may be others. Among the other activities and traditions which might have also prompted the integration of paper folding as a scientific procedure were the novel printing techniques developed during the 15th-16th century (such as imposition, see Clemens and Graham, 2007, pp. 14-16, as well as the abundance of paper instruments, see Karr Schmidt, 2006.
} 


\section{Napkin folding and folded polyhedra}

When paper was introduced in Europe, there was already a long tradition of folding fabrics and napkins. We follow here the account given in Joan Sallas' book Gefaltete Schönheit (2010), which extensively surveys the history of napkin folding in Europe, concentrating mainly on the period starting from the 16th century. ${ }^{8}$ As Sallas indicates, during the 16th and 17 th centuries, folding napkins was an essential and highly valued component of the court culture. The art of napkin folding may be explained as a new developing means of displaying power and splendour among the high society during these centuries, where napkins changed their role from protection of the precious clothes to serve a more decorative function, which was far removed from the food itself.

During the Baroque era, this particular art form culminated in the demand for appropriately trained staff. Entirely new occupations arose in the serviceprofessional folders became much sought after as specialists in the new folding art, who were able to fold complex and attracting shapes, for example, in the form of animals. Gradually, the training of the napkin crews also took place outside the courts.

At the University of Padua, one could even study the subject at the beginning of the 17th century under Mattia Giegher, who came from Bavaria (Sallas, 2010, pp. 60-62, 70-72). Giegher was among the distinguished experts in the art of napkin folding. The young Giegher travelled from Bavaria to Italy around 1616 and settled in Padua where he became an expert carver. Due to his knowledge in the art of table serving and of napkin folding, he was a teacher at the University of Padua and wrote, among other books, the manuscript Li tre trattati (1629), in which the short treatise Trattato delle piegature shows for the first time models (with figures) of folded shapes (mostly animals) (see also Sallas, 2010, pp. 25-26, 36). Figure 1 presents several illustrations of these models. It is clear from Giegher's text that the process was not explicitly mathematical, ${ }^{9}$ even though geometrical reasoning and precision—such as folding a square piece of fabric into congruent rectangles, into smaller squares and into triangles - was necessarily mathematical, even if this was only implicit. However, several of Giegher's instructions do point out that a fold into a square shape is needed (Giegher, 1629, pp. 2-3).

8 For more detailed research on the connection between napkin folding, paper folding and mathematical education in the 18th and the 19th century, see Friedman, 2018, Section 3.2.1.2.

9 By that we mean that the explicit goal of Giegher's exercises and instructions was not to solve mathematical problems. 


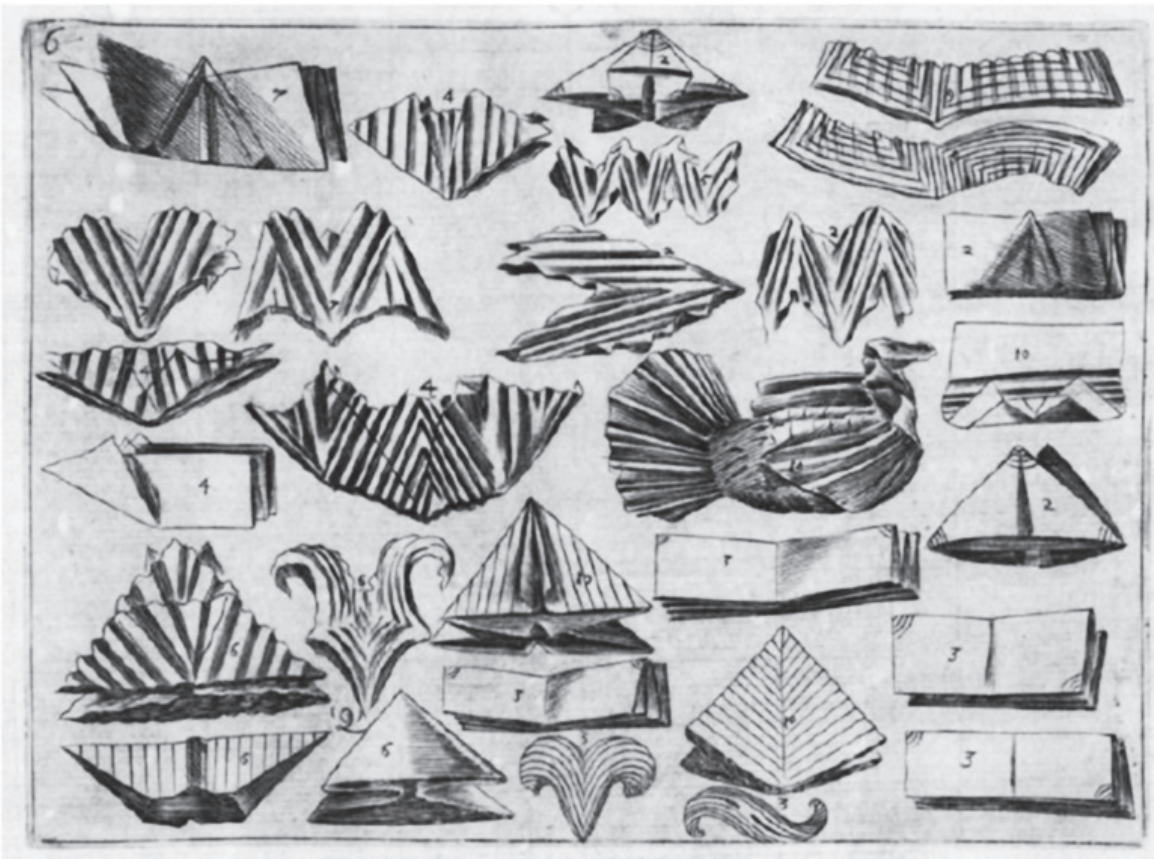

Figure 1. Plate 6 from Giegher's Trattato delle piegature (Giegher, 1629)

In 1639, Georg Philipp Harsdörffer translated Giegher's work into German, also publishing his own manuscript on this theme: Vollständiges und von neuem vermehrtes Trincir-Buch ('Complete and newly extended carving book'). Published in 1652, Harsdörffer's own book, as will be shown in the following sections, contributed to the integration of folding in recreational mathematics. Following Harsdörffer and Giegher's works, in 1657 Andreas Klett published a book on napkin folding, entitled Trenchier- und Plicatur-Büchlein (cf. also Peter, 2008, pp. 88-89). Klett was the first to introduce the terms Bergfalte ('mountain fold') and Talfalte ('valley fold') (Sallas, 2010, p. 36), terms that are still in use today in origami. In 1677, a new edition of Klett's book was issued, called Neues Trenchierund Plicatur-Büchlein. In comparison to Harsdörffer's work, which began with folding instructions and then with explanations on the art of carving, Klett reversed the order of presentation, with the part on napkin folding being considerably shorter than in Harsdörffer's work (see Klett, 1677, pp. 107-120). ${ }^{10}$

10 However, Klett, similarly to Harsdörffer, emphasises at the beginning of his treatment, though concisely, several types of fundamental folding: straight, round, in diagonal position to each other, noting that the height of each fold should be equal to the other folds (Klett, 1677, p. 107). 
After some thirty years, their works had spread far and wide in Europe and slowly gained recognition among the lower classes (Sallas, 2010, pp. 36, 44, 46). The great number of books on the art of carving, which, influenced by Giegher's book, usually contained chapters on the folding of napkins, as well as the numerous books on napkin folding alone, serve as evidence that napkin folding and its geometrisation ${ }^{11}$ was also widespread (see Gloning, 2003, pp. 247248, especially fn 52). Whereas Giegher's books were directed at specialists, apprentices of the high court, one can find evidences that in 1705 napkin folding was starting to be integrated into children's curriculum; indeed, the theologian and pedagogue August Hermann Francke (1663-1727) gave lessons on napkin folding to children in his orphanage (Sallas, 2010, pp. 116-117). ${ }^{12}$ However, as we will show later, it was also integrated within recreational mathematics, dedicated for adults, and not necessarily for the high court.

Another mathematical folding tradition which was integrated into recreational mathematics was Dürer's presentation of polyhedra in the form of folded nets. Dürer was one of the most versatile German artists of the Renaissance period. His manuscript Underweysung der Messung, published in 1525, with a second edition in 1538 , consists of four books. In the fourth book he presented, systematically for the first time, ${ }^{13}$ drawings of nets of polyhedra — of the unfolding of the faces of these solids along their edges made in this manner so that the model may be folded up from this unfolding. Indeed, while taking into consideration the Platonic and Archimedean solids, Dürer drew these polyhedra following two traditions in order to investigate them: the then well-known methods of perspective and the almost unknown method of unfolding a three-dimensional polyhedron onto the plane (see Fig. 2). ${ }^{14}$

11 By 'geometrisation' we mean the presentation of napkin folding as an activity, which explicitly transmits geometrical knowledge regarding several shapes (e.g., parallel lines, congruent triangles, etc.)

12 Friedrich Fröbel (1782-1852) also integrated paper-folding activities in his curriculum for kindergartens; in 1850 one finds him systematically treating paper folding mathematically; see Fröbel, 1874, p. 371-388. It is also clear that paper folding was an activity that could be found, even if partially, in kindergartens, before Fröbel re-conceptualised it as a mathematical activity: for example, during the first half of the 19th-century, paper folding found its way into nurseries, as indicated in Heerwart, 1896, p. 4, see also Sallas, 2010, pp. 128-129. Concerning the 19th century Fröbelian conception of mathematical folding, see Friedman, 2018, Section 3.2.1.2.

13 For possible mathematicians who might have influenced Dürer in developing this method, such as Charles de Bovelles, see Heuer, 2011, pp. 262-264. Indeed, although one can find already simple and partial nets in Geometrie en françoys by de Bovelles (1511), Dürer was the first who introduced systematically polyhedra by folding nets.

14 Regarding Dürer's nets and his unfolded polyhedra, see Staigmüller, 1891, pp. 32-37; Steck, 1948, pp. 64-75; Richter, 1994, pp. 54-58. For an excellent survey of Dürer's folds in general, see Heuer, 2011. 

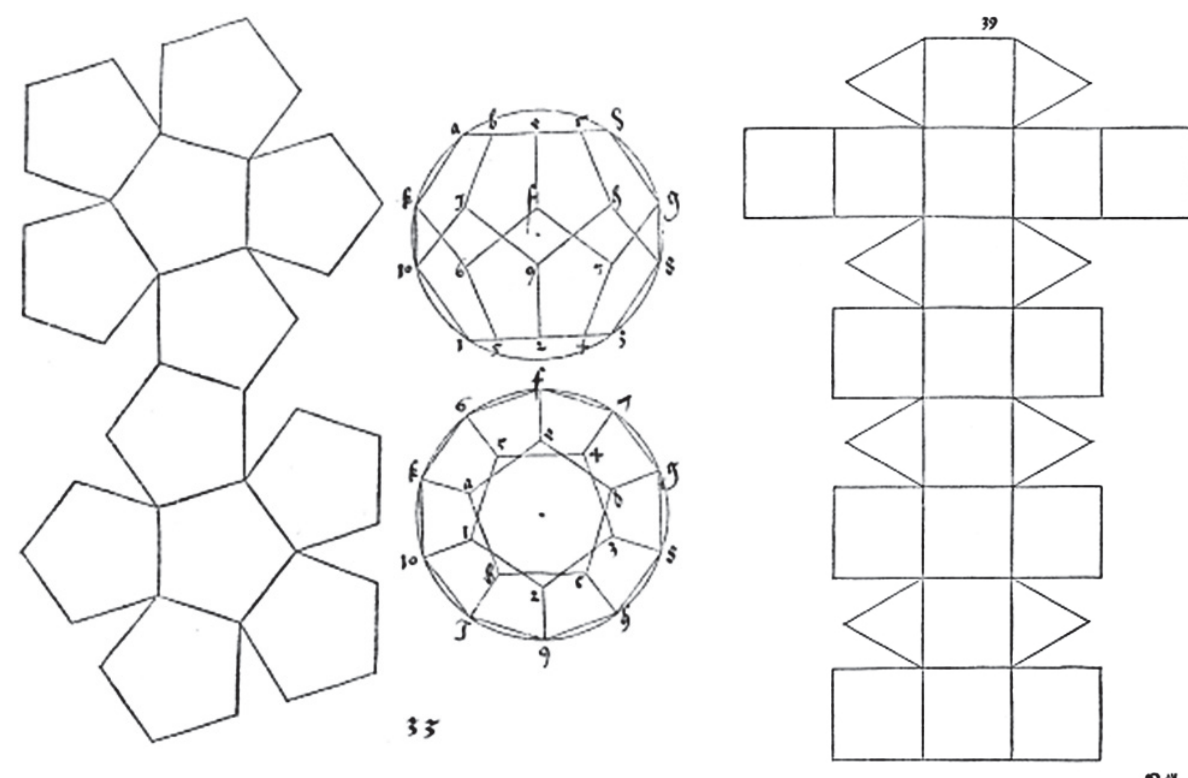

Figure 2. Two of Dürer's nets: The dodecahedron (with two perspectival drawings) and the rhombicuboctahedron (Dürer, 1977 [1525], pp. 324, 338).

Although Dürer drew all the Platonic solids with the two methods, in 1525 he only drew several of the Archimedean ones, and for these, only nets. ${ }^{15}$ This might indicate that Dürer put more emphasis and importance on nets rather than on perspective, offering a complementary way to present these solids. This method was indeed complementary since one needed to fold these nets, and not just to visualise them: hence it was a tactile-haptic practice, and not necessarily strictly a visual one. As will be shown, these tactile practices were exactly what the recreational mathematics tradition promoted. Already in Dürer's work, as Jeanne Peiffer argues, the technical drawings in Underweysung der Messung can be considered "as mediators between practical and theoretical knowledge" (Peiffer, 2004, p. 245).

Dürer's methods of the presentation of polyhedra spread quickly. His contemporaries and followers, such as, for example, Wolfgang Schmid in his 1539 book Das erste Buch der Geometria and Augustin Hirschvogel (1503-1553), in his book Geometria, published in 1543, followed Dürer's techniques and drawings of unfolded polyhedra. And though a full survey of Dürer's influence is

15 In the 1538 edition of Underweysung der Messung, Dürer added two new nets of Archimedean solids: the net of the truncated icosahedron and the net of the icosidodecahedron. 
not given here, the following sections show that these methods were considered as a part of recreational folding. However, it is important to note that Dürer did not consider his own research on folding as recreational, since it appeared only as a way to represent polyhedra, together with perspective. In order to see how the integration of these folded nets and, in general, of folding in recreational mathematics took place, we now turn to Daniel Schwenter.

\section{Daniel Schwenter: the first volume of Erquickstunden ('recreational hours')}

Daniel Schwenter (1585-1636) was a German orientalist and mathematician. Born in Nuremberg, he studied oriental languages and mathematics at the University of Altdorf, where he was also a student of the mathematician and astronomer Johann Richter (Johannes Praetorius). He was a professor of oriental languages (starting from 1606) and eventually also of mathematics (in 1628) at the University of Altdorf.

As a mathematician, Schwenter wrote several well-known books for his time: Die Beschreibung des geometrischen Tischleins ('A description of geometric little tables', 1619), Geometria practica nova (1625-1626), and especially importantly for this study, the first volume of Deliciae physico-mathematicae oder mathematische und philosophische Erquickstunden ('Physical-mathematical delights or mathematical and philosophical recreational hours', 1636), published posthumously by Harsdörffer, which was one of the first books in the German language on recreational mathematics. Also important to notice is Schwenter's knowledge in geometry, as his book Geometriae practicae nova, which was published posthumously in 1641, described and depicted the use of geometry in land survey and measurement, presenting also several instruments to perform these measurements.

As indicated above, Schwenter obtained Leurechon's book Récréation mathématique, and, as he was fascinated by it, he either gave it to be translated (cf. Cantor, 1891), as he hardly knew French, or he was at least inspired from several of the activities there, combining them together with several of his own activities. Albrecht Heeffer indicates that

[David] Singmaster completely rejects this attribution [that Schwenter's book was a translation] as 'quite wrong'. Indeed Schwenter's book cannot 


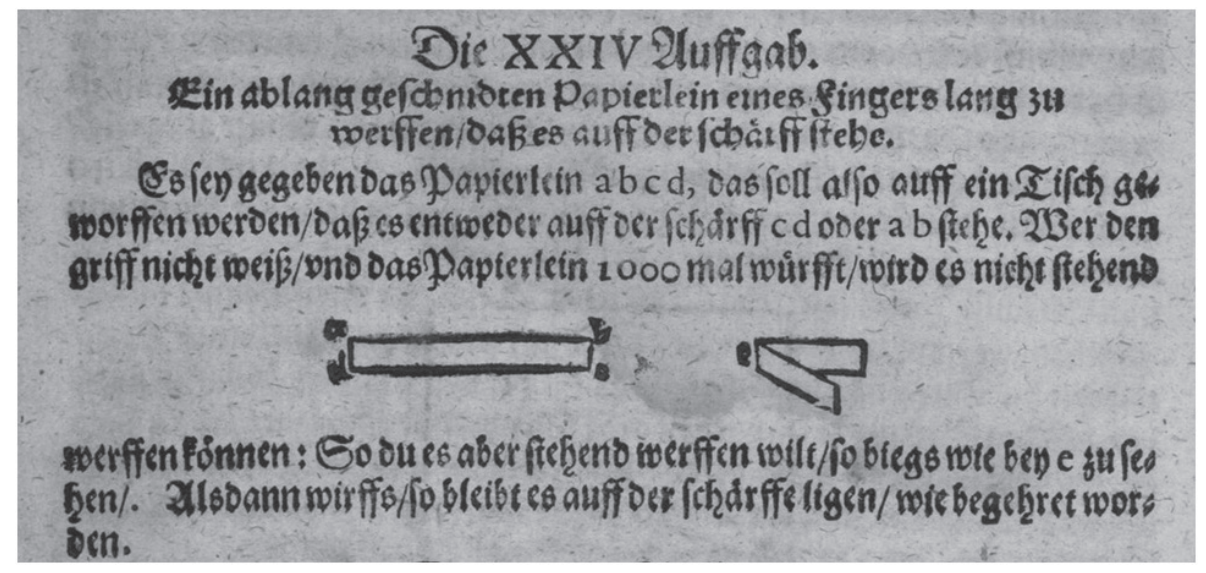

Figure 3. Schwenter's exercise of folding a piece of paper (Schwenter, 1636, p. 568).

be considered a sheer translation, but closer comparison reveals a systematic treatment of the problems from Récréations Mathématiques. Almost 100 problems can be matched between the two works. (Heeffer, 2004, p. 7) ${ }^{16}$

Leurechon's activities, as we noted in the previous section, did not take folding into account. Schwenter's work, however, did, although the number of activities and games that deal directly with folding and mathematics is limited. Numerous of Schwenter's exercises do deal with paper and related operations with it: cutting, rolling, folding, and bending. ${ }^{17}$ Thus, for example, Schwenter presents a rolling exercise of three rectangular strips of paper of different lengths, such that the shortest would be in the middle (Schwenter, 1636, p. 413). Other exercises include cutting a paper into various geometric forms (Schwenter, 1636, pp. 145, 411) or folding a paper in form of a letter (Schwenter, 1636, pp. 521-522). Two different exercises, however, show the more geometrical characteristic that folding has for Schwenter. The first exercise instructs how to throw a rectangular strip of paper (whose vertices are denoted by $a, b, c, d$ ) such that it would always land on its edge (see Fig. 3).

Schwenter instructs to fold the edge $b c$ on $a d$, indicating that in that way every time one would throw the strip, it would land on its edge. This experiment succeeds only by the implicit fact that the crease $e$ created by folding $b c$

16 The plural form of Récréation mathématique, with two "s", started to be used with the 1628 edition, see Heeffer, 2004, p. 1.

17 Note that these activities reappear in Fröbel's list of gifts and occupations for children (see, e.g., Fröbel, 1874), though a direct connection between the 17th-century tradition of paper folding and the 19th-century Fröbelian conception of kindergarten activities may be only implicit. 


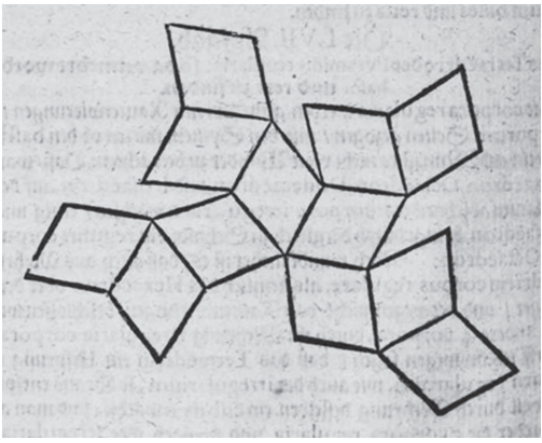

Figure 4. Schwenter's net

composed of twelve rhombi

(Schwenter, 1636, p. 226). on ad is in fact parallel to both edges; otherwise the obtained form would be unstable.

The second example is based on the Dürerian practice of folding nets. Schwenter, born in Nuremberg, knew the work of Dürer as well as the works of his followers: Hirschvogel and Schmid (who Schwenter named "Wolff Schmids"). ${ }^{18}$ In the first volume of Deliciae physico-mathematicae Schwenter presents several of the nets that one should fold in order to obtain several polytopes, which were not

known to Dürer or to his followers. After describing Dürer's procedure to obtain the unfolding of the nets of the Platonic solids (Schwenter, 1636, p. 225), ${ }^{19}$ he gives the following exercise: "on a cube being increased: find the projection and the net". ${ }^{20}$ It appears that Schwenter is asking to find the projection and the net of a polytope with twelve rhombi as faces, which correspond to the twelve edges of the cube. The net Schwenter provides (see Fig. 4) is not drawn in any other account on polytopes and their nets during this period or before (cf. Friedman, 2018, Sections 1.1 and 1.2.2), and it might correspond to the net of the rhombic dodecahedron, though it is not clear from Schwenter's description which polytope should be constructed from this net. A similar exercise (numbered LX) is given subsequently: "on the dodecahedron being increased with pyramids: find the projection and the net". ${ }^{21}$ As a solution to this exercise, Schwenter provides half of net of the desired polytope, composed of fifteen rhombi. ${ }^{22}$ Again, this net cannot be found in other works on this subject at that time. Schwenter, with his new nets, is referring directly to the methods of Dürer, by presenting

18 Schwenter mentions them in Die Geometria practica nova, see Berns, 1991, p. vi. On the different way to represent regular polyhedra in the 16th and 17th centuries in Germany, see Richter, 1995. On the nets and three-dimensional models of Dürer, Hirschvogel and Schmid, see Richter, 1995, pp. 54-66.

19 Schwenter does not mention Dürer's name explicitly in this specific passage, but mentions his name several times in the book and also a few pages before giving this exercise (Schwenter, 1636, p. 218).

20 "Eines Hexaedri oder Cubi so da vermehrt worden: basin und rete zu finden" (Schwenter, 1636, p. 225).

21 "Des Dodecaedri, so da mit Pyramidibus vermehret wird: basin und rete zu finden" (Schwenter, 1636, p. 228).

22 "halbes rete" (Schwenter, 1636, p. 228). 
two complementary ways of presenting a polyhedron: visually, via projection and haptically, via its net, which should be folded, as Dürer and his followers emphasised.

With these numerous examples, it is already clear that folding was for Schwenter a procedure to exemplify geometrical constructions, especially following the tradition of using nets to construct polyhedra. We will deal more broadly with how folding reflected the interweaving between material exercises and mathematics, but before that a discussion on Harsdörffer, and how he further continued Schwenter's work, is needed.

\section{Georg Philipp Harsdörffer: the third volume of Erquickstunden and Trincir-Buch}

Georg Philipp Harsdörffer (1607-1658), a German Baroque poet, studied law at Altdorf and Strasbourg. Owing to his knowledge of languages, he gained the appellation "the learned". In 1644 he founded at Nuremberg, together with Johann Klaj, the order of the Pegnitzschäfer, a literary society. ${ }^{23}$ Among his works are the Poetischer Trichter. Die Teutsche Dicht- und Reimkunst ('Poetic funnel: German poetry and rhyme art, 1647), Frauenzimmer Gesprächspiele ('Women's conversation games', 1644-1657), Vollständiges und von neuem vermehrtes Trincir-Buch (1652), and of course the second and the third volumes of Deliciae physico-mathematicae oder mathematische und philosophische Erquickstunden, published in 1651 and 1653, respectively. We will first survey the main books of Harsdörffer, which point to an encounter between folding and mathematics in his work, and then discuss the historical and epistemological framework in which Harsdörffer's conception of folding is located.

Although the second volume of Deliciae physico-mathematicae does not contain any reference to folding, the third volume, published two years later in 1653, has exercises that refer to two essential traditions that conceptualise folding mathematically. The first tradition continues what was already present in Schwenter's work: the nets of polyhedra. Harsdörffer presents the following question: "Question XXXI: how one makes the cornered mirror ball?" ${ }^{24}$ The answer is given by allegedly folding the net of a rhombicuboctahedron: "setzet

\footnotetext{
23 The secondary literature on Harsdörffer is vast, see, e.g., Gerstl, 2005.

24 “Die XXXI Frage: Wie man die eckigen Spiegelkugel mache?” (Harsdörrfer, 1653, p. 252).
} 

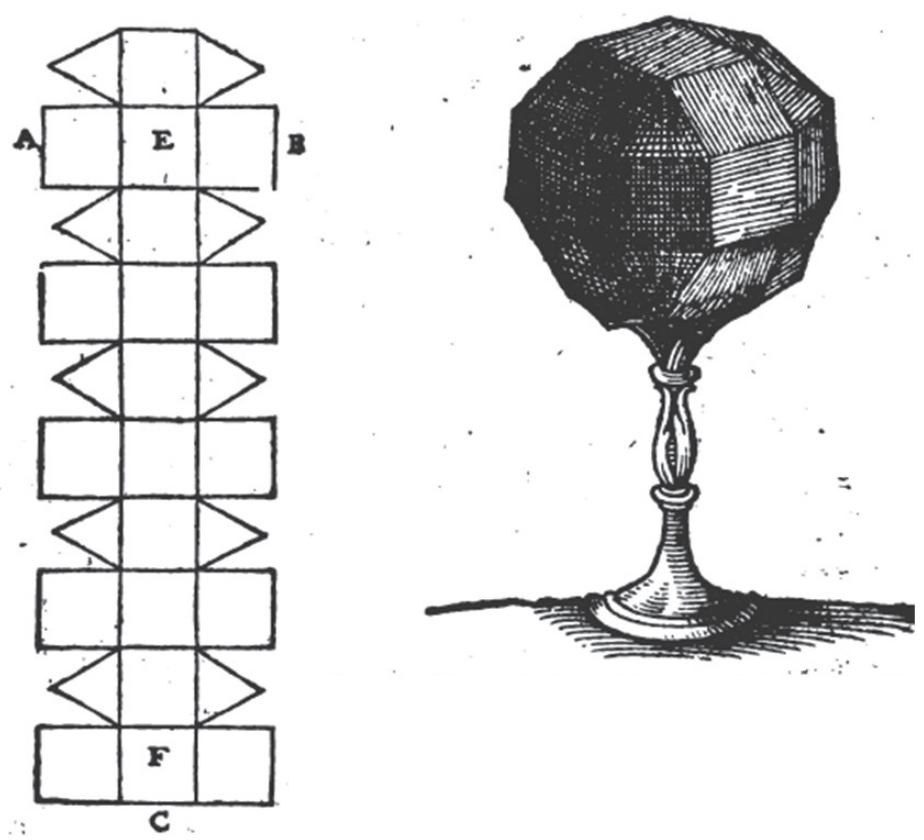

Figure 5. The rhombicuboctahedron of Harsdörffer: the three-dimensional model and the incorrect net (Harsdörffer, 1653, p. 252).

man sie [die Figur] zusammen" (Harsdörffer, 1653; see Fig. 5). ${ }^{25}$ However, while the drawing of the three-dimensional model depicts the rhombicuboctahedron correctly, the depicted net has twenty squares and ten triangles, and hence is incorrect, as the rhombicuboctahedron has eighteen square faces and eight triangular faces. This mistake is quite surprising, as the net of the rhombicuboctahedron was already drawn by Dürer correctly in 1525 in his book Underweysung der Messung, as seen in Figure 2. It might be that the origin of Harsdörffer's error, in comparison to Schwenter, is that he did not know Dürer's work well enough, or the works of his followers.

The second series of activities points to another tradition of transmitting geometrical knowledge by means of folding — napkin folding. In a short survey Harsdörffer discusses the question of the "folding of tablecloths", ${ }^{26}$ showing different ways to fold these fabrics. Harsdörffer indicates immediately at the

\footnotetext{
25 "Die Spiegel werden zerschnitten / wie der Grund der Kugel die Figur ausweiset / und alsdann setzet man sie zusammen / so beschauet man darinnen ein Angesicht auf so viel Weise / als man Spiegel zu Gesichte bringet und sind diese Kurzweilen / mit geringen Unkosten anzurichten".

26 "Von Faltung der Tischtücher" (Harsdörffer, 1653, pp. 189-191).
} 
beginning the connection to geometry: "The combination and folding of tablecloths [...] has a great relation to the art of measurement [Mäßkunst], as it consists of straight parallels lines, unidirectional lines, as well as in circular arcs" (Harsdörffer, 1653, p. 189). After giving several explanations and depictions (see Fig. 6), Harsdörffer mentions that in fact one can try these exercises with a folded paper,

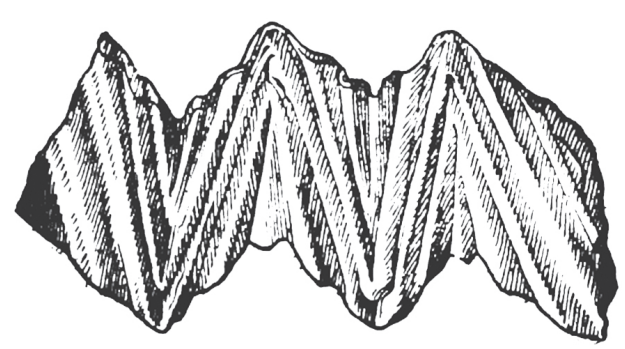

Figure 6. One of Harsdörffer's basic forms of cloth folding in the third volume of Deliciae physico-mathematicae (Harsdörffer, 1653). although he prefers the folding of a fabric: "Whoever does not want to try it on a tablecloth can do it with paper; although the hand is not as good as the delicate cloth". ${ }^{27}$

Harsdörffer's interest in folding cloths and napkins and the way it is related to geometry is more explicit and elaborate in his 1652 book Trincir-Buch ('carving book'), influenced by Giegher's work. ${ }^{28}$ It is there that Harsdörffer emphasises which kind of (mathematical) knowledge is transmitted via folding.

After the introduction, the book immediately presents an account on napkin folding called Von den Taffeldecken und desselben Zugehör ('On the table cloths and their accessories'), an account that is considerably longer than the one to be found in the third volume of Deliciae physico-mathematicae. At the outset, Harsdörffer (1652, p. 16) already mentions that the tradition is also to be found in France. Moreover, in Deliciae physico-mathematicae, Harsdörffer (1653, p. 191) notes that this tradition was also common among the princes of Nuremberg. Hence one can deduce that German and French high courts were sufficiently familiar with this tradition, even though it was less developed in France, as will be explained in the next section. Showing several basic forms of folding napkins (see, e.g., Fig. 7(1)), Harsdörffer notes that all the segments must be equal to each other. ${ }^{29}$ This indicates, as seen in the description given in Deliciae physicomathematicae, a direct connection to geometry and the "art of measurement", as folding enables also the comparison of the length of one with respect to another.

\footnotetext{
27 "Wer es an einem Tischtuch nicht probiren will / kan es mit Papyr machen / wiewol solches der Hande nicht so gefolgig ist / als das gelinde Tuch" (Harsdörffer, 1653, p. 191).

28 Indeed, Harsdörffer's work includes several drawings that already appear in Giegher's work.

29 "Hier ist auch zu mercken / daß alle die Falten fein gleich seyn müssen" (Harsdörffer, 1652, p. 22).
} 
Harsdörffer (1653) also notes that one can make exercises with paper first, as with this material the mistakes can be easily corrected. Another direct connection to geometry is to be noticed when Harsdörffer points out that several of the folded shapes are derived from the square (or from the initial act of squaring, "Vierung"), i.e. the square itself may be seen as the basic form. ${ }^{30}$

Moreover, it is essential to note that while discussing folding techniques, Harsdörffer presents three types of knowledge which can be transmitted through folding. Referring to the folds appearing in Figure 7(2), he notes the following:

Many things can be said and not drawn: Many [things] can be painted and not said: Many [things] cannot be expressed, neither with painting nor with words / among these are also many works of folding / and it is in these figures to see / how the beginning and the foundation 1, 2, 3, 4 is done. (Harsdörffer, 1652, p. 32) (11 $^{31}$

For Harsdörffer, the following three knowledge practices ${ }^{32}$ exist: a symbolicallinguistic one, transmitted by means of words; a visual one, transmitted with pictures and drawings; and a practical-tactile one that cannot be "expressed with painting [or] with words" and includes the folding techniques. Considering the historical mathematical framework, one may assume that with linguistic knowledge Harsdörffer is referring to the symbolical-algebraic methods advanced by Descartes whose works he knew. ${ }^{33}$ The mention of painting and drawing are an implicit reference not only to the works of Dürer and his followers, who drew several mathematical objects, such as the numerous Platonic and Archimedean solids, but also to Schwenter's Geometriae practicae novae, in which one can find, for example, several drawings of conic sections. Folding and the geometrical knowledge that is derived from it are considered as knowledge transmitted neither through words and (algebraic) symbols nor with images or diagrams, but through practical-tactile activity performed and practised by hand. And, as Harsdörffer

30 "Wie man von den Fatscheinlein soll Blätter / Orgel / Linien ec. machen / und sind die Striche die Falten / als der Anfang zu folgenden Figuren / so auß der Vierung herkommen." ('How one should make from napkins leaves, organ, lines, etc.; the strokes are the folds as the beginning of the following figures, which are derived from the square.'; Harsdörffer, 1652, p. 26).

31 "Viel Sachen lassen sich sagen und nicht mahlen: Viel lassen sich bilden und nicht sagen: Viel können mit dem Gemähl und mit den Worten nicht außgedrucket werden / darunter auch viele Arbeit mit Plicaturn / und ist in dieser ersten Figur zu sehen / wie der Anfang und die Grundlegung 1.2.3.4. gemacht wird [...]."

32 These three practices can be also seen as an early forerunner of another principle in the didactics of mathematics (cf. Jerome Bruner et al., 1971) from the 1970s: the so-called E-I-S principle, or the enactive-iconic-symbolic separation into three kinds of knowledge to be transmitted.

33 Harsdörffer (1651, p. 195, see also Heinecke, 2011, p. 260) refers to Descartes in the second volume of the Deliciae physico-mathematicae. 
(1652, p. 24) mentions, this practical activity also enables the invention of new forms, which is not evident with drawing or written description.

With the numerous references to folding that can transmit geometrical knowledge, we claim that folding, as an activity within recreational mathematics, can be considered, at least starting with Harsdörffer, as what is found at the intersection of two traditions: the first, the Baconian conception of science, by which Harsdörffer was strongly influenced (Heinecke, 2008), demanding the necessity of experiment in order to formulate the laws of nature; and the second, the practising of amusements in order to transmit knowledge. To recall, Francis Bacon's new method was presented in his 1620 book Novum Organum, calling for the accumulation of knowledge about the natural world via experiments, from which one derives the laws of nature. He suggested that instead of the deductive method, one should "challenge" nature by inductive experiments, which would lead to the formulation of universal laws. These experiments should, following Clifford D. Conner, also take into account and experiment with the craftsmen's knowledge of nature. Conner adds: 
Accordingly, Bacon advocated compiling a "history of arts" [...] of craft knowledge. The "particular arts to be preferred" in such a project $[\ldots]$ are those that "exhibit, alter and prepare natural bodies and the material of things such as agriculture, cookery, chemistry, $[\ldots]$ and the like." He also categorized as less useful (but by no means to be neglected) "weaving, carpentry, architecture [...]”. (Conner, 2005, pp. 250-251; Bacon, 1960, p. 278)

It is essential to note that also Descartes does not neglect the "simplest and less exalted arts", as can be seen in his Rules for the Direction of the Mind. In the Tenth Rule, Descartes notes that "in order to acquire discernment we should exercise our native intelligence by investigating what others have already discovered, and methodically survey even the most insignificant products of human skill, especially those which display or presuppose order." As examples of the "simple" arts, which "display or presuppose order", Descartes offered weaving, carpet-making and embroidery, but also, and more important for our study, "number games and any games involving arithmetic." These activities, according to Descartes, "exercise our native intelligence, provided of course we discover them for ourselves and not from others..." (Descartes, 1988, pp. 10-11) Although Descartes' Rules was published only in 1684 in Dutch and in 1701 in Latin, both the Baconian and the Cartesian conceptions reflect the need to discover mathematical—and hence geometrical-laws via an inductive experiment, which includes in it learning from and experimenting with the crafts, which "exhibit, alter and prepare [...] material of things", according to Bacon. These crafts involve in a fundamental way a haptic-tactile aspect, through which geometrical knowledge-in the case of paper folding-is transmitted and discovered.

Concerning Harsdörffer's adaptation of Bacon's ideas, Jörg Jochen Berns (1991, p. xxx) indicates that although Bacon was especially important for Harsdörffer he was more interested in games and amusement. Nevertheless, as can be seen above, these two traditions do not contradict each other. Following Berthold Heinecke (2008; see also Braungart, 2011), we would like to call Berns' assessment into question by stressing Heinecke's statement that "Harsdörffer's concept of mathematics is much broader than modern concepts, considering 'mathematical' virtually anything having to do with quantification" (Heinecke, 2008, p. 393). This conception reflects the Cartesian conception presented above, and shows the role folding played - a mathematical one-in Schwenter's and Harsdörffer's writings. Indeed, while numerous of Schwenter's exercises deal with paper-related operations (cutting, rolling, folding, and bending), this was then 
presented, under the editing of Schwenter's writings by Harsdörffer, as reflecting a more Baconian conception of science (Heinecke, 2011, pp. 251-254). There folding is not only meant for entertainment and the creating of illusions, but also for showing geometrical forms enhancing a practical knowledge that is not merely accomplished in a linguistic or visual fashion. What this comes down to is that folding implies a different form of reasoning - a practical one that leads to geometrical understanding. It presents a form of "learning by doing", a method which is also present in Harsdörffer's Frauenzimmer Gesprächspiele (Wurst, 2004). For Harsdörffer, who reformulated the ideas of Giegher and was influenced by Schwenter and Bacon, "[p] ractical application and activity are the key to the secrets of nature; the meaning and purpose of the sciences is practical use for humankind" (Heinecke, 2008, p. 400).

As mentioned earlier, it seems that the nets of polyhedra tradition, introduced by Dürer and completed by his followers, was less developed in France than in Germany. Moreover, the implicit transfer of napkin-folding tradition to recreational mathematics books came to France later than Germany. The following sections survey two major French works-falling within both the napkin-folding and recreational mathematics traditions-in which folding procedures are presented, and sometimes illustrated.

\section{Le cuisinier françois by François Pierre de La Varenne}

Le cuisinier françois was written in 1651 by François Pierre de La Varenne (1618-1678), an equerry of the Marquis d'Uxelles. ${ }^{34}$ This book, dedicated to cooking, played an essential role in the history of French cuisine because it marks the passage from medieval to modern cooking. This explains why it has been republished many times, with additional comments and recipes. ${ }^{35}$

The 1651 edition of Le cuisinier françois presents nothing in the way of napkin folding, but in the anonymously (Sallas, 2010, p. 44) published 1662 book L'escole parfaite des officiers de bouche, one finds many materials (according to the National Library of France) taken from Le cuisinier françois and a section

\footnotetext{
34 La Varenne wrote three other books on pastry (1653), jams (1664) and stews (1668) for a professional audience. Among a group of French chefs, he worked on the codification of French cuisine, setting down the culinary innovations achieved in France in the 17th century, and giving systematic explanations on the preparation of many dishes.

35 The book is still sold online, the latest edition is from 2016.
} 
of fifteen pages in the chapter Sommelier Royal ('Royal sommelier') devoted to "[f] amiliar instructions on how to properly learn to fold all types of table linen, and into any kind of shape" ${ }^{36}$ (Ribou, 1662, p. 94). As Sallas points out, the 1662 book not only integrated material from Le cuisinier françois, but also used the books of Giegher and Harsdörffer as sources. Sallas (2010, p. 44) considers this book, printed by Pierre David's widow and Jean Ribou in Paris, as the first French text on napkin folding and their layout on a table.

The fifteen-page section presents twenty-six different shapes, which can be formed by folding a napkin. Most of them are animals (cock, hen, chick, pigeon, partridge, pheasant, hare, pig, dog, turbot, pike, carp, tortoise) and others are catholic symbols such as a mitre, the Holy Spirit cross, or the Cross of Lorraine. The author explains that, first of all, it is necessary to know properly how to "bastonner et friser" (Ribou, 1662, p. 94). ${ }^{37}$ These two actions are "the principal knowledge that one must have to work on practising the nice curiosity, which is taught here" (Ribou, 1662, p. 94).$^{38}$ In a word, "bastonner et friser" are the basis of any shape one would like to create.

In order to "bastonner", one needs to take the napkin, "fold it crosswise and crease it into small pleats with the fingers, the lowest and finest possible" (Ribou, 1662 , p. 94) ${ }^{39}$ No illustration is provided in this section, but we assume that the procedure is similar to the one represented in Figure 7(1). Once the napkin is "bastonnée", one needs to "curl it from the middle" (Ribou, 1662, p. 95), ${ }^{40}$ and then create all kinds of covers. Most of the shapes are used to wrap the bread in an elegant way. Measurements are often indicated precisely where the napkin is to be folded: "do strips one inch large", ${ }^{41}$ or "carry on to six or eight fingers next to the hem" (Ribou, 1662, p. 97). ${ }^{42}$

As mentioned above, this section of L'escole parfaite des officiers de bouche has no drawings to illustrate the different shapes, thus it is quite difficult to properly

\footnotetext{
36 "Instructions familières pour bien apprendre à plier toutes sortes de linges de table, et en toutes sortes de figures."

37 We deliberately keep here the French terms, since the contemporary meaning of the verb bastonner is completely different: it could be translated as 'cudgel', which would be senseless in that case.

38 "[...] parce que ce sont les deux connoissances principales que doit avoir celui qui veut s'employer à la gentile curiosité qui est ici enseignée".

39 "il faut prendre une serviette, la plier de travers, et la plisser par petits plis avec les doigts, le plus bas et le plus délié qu'il se peut".

40 "il la faut friser par le milieu".

41 "Faites des bandes d'un pouce de large".

42 "continuez jusques six ou huit doigts près de l'ourlet".
} 
understand the procedures required to create them (the author assumes that anyone who is willing to try the folds already has prior knowledge of the subject). This observation brings us to the idea that Giegher's book was not so commonly known in France, otherwise we think that similar illustrations would have been displayed in L'escole parfaite. This is contrary to what Sallas mentions concerning Giegher's influence, as noted above. Furthermore, unlike Giegher, the author of L'escole parfaite does not indicate that an initial square shape is needed to fold the napkin. It is clear that the process of folding presented here for French equerries was not mathematical, as they were essentially concerned with culinary facts.

The tradition of napkin folding was important at high courts during the 16th and the 17 th centuries, and - as we saw in the previous section with Harsdörfferwas transferred into recreational mathematics, especially in Germany. It seems, however, that the interaction between these two fields was less obvious in France. The following section supports this idea, taking a closer look at one of the most important books on recreational mathematics of the 17th and 18th centuries: Jacques Ozanam's Récréations mathématiques et physiques.

\section{Jacques Ozanam: the republications of his Récréations mathématiques et physiques (1723 and 1799)}

Jacques Ozanam (1640-1718) was a French mathematician, more particularly known for his writings about trigonometric and logarithmic tables. His original intention was to become a clergyman, but his passion for mathematics led him to give up religious education after his father's death, when he was fifteen. ${ }^{43}$ Then he became a private teacher of mathematics (Abraham de Moivre (1667-1754) was one of his students) in Lyon and in Paris. In a scientific realm dominated by Leibniz (1646-1716), Ozanam was not a leading scholar, but a respected mathematician. In 1670, at the beginning of his career, he published the most precise logarithmic and trigonometric tables of his time. In the 1690s, he published his major works: Dictionnaire de mathématiques (1691), Cours de mathématiques (1693) and Récréations mathématiques et physiques (1694). In 1707, he became a "student" of the French Academy of Sciences and in 1711 an associated member. He died suddenly in 1718 of apoplexy.

43 The biographical information of this section comes from the praise de Fontenelle wrote in 1719 on Ozanam for the French Academy of Sciences, see Fontenelle, 1719. 
The first edition of Ozanam's Récréations mathématiques et physiques dates back to 1694; many republications, completed with revisions and additions, were to follow, such as Edmé-Gilles Guyot's 1769 edition or Jean-Etienne Montucla's 1778 edition. During the 18th century and the beginning of the 19th century, Récréations mathématiques et physiques was also translated into many European languages (Chabaud, 1994, p. 226). Regarding these numerous republications and translations, William Schaaf notes: "Ozanam can be regarded as the forerunner of modern books on mathematical recreations" (Schaaf, 1963, p. 1). Indeed, Ozanam's Récréations mathématiques et physiques marked a turning point for the genre of recreational mathematics; the fact that the preface remained unmodified between 1694 and 1770 is indeed a sign of this. Moreover, Ozanam gave mathematical recreations a place in an ancient tradition, that is, a tradition in which mind games can be playful and pleasant, but with an educational aim. ${ }^{44}$

The 1694 edition of Ozanam's Récréations was published by Jombert in Paris in two volumes; the first one deals with many problems of a different nature: arithmetics, geometry, optics, gnomonics and cosmography, while the second volume deals with mechanics, pyrotechnics, and physics and concludes with a Traité des horloges élémentaires ('Treatise on elementary clocks'). In this edition no consideration is given to folding paper (or any other material which could be folded, for that matter). In 1723, the book was posthumously republished in four volumes (still by Jombert) with major additions, presumably due to Martin Grandin, a teacher of philosophy at the College of Navarre. ${ }^{45}$ The fourth volume of the 1723 edition is devoted to mathematical and physical recreations on natural and artificial phosphorus, permanent lights, but also on game-bag and cup tricks. Among the twelve cup tricks, there are also several card tricks, magical knots and sleight of hand tricks (49 in total), one of them consists of folding a piece of paper "to do a large number of different shapes" ${ }^{46}$ (Ozanam, 1723, p. 432). The author suggests a very large sheet of paper be used, divided into eight parts (the fourth and the fifth are larger than the others), as shown in the first illustration of Figure 8. Then the paper should be folded as the $\mathrm{N}$ piece with the lines obtained by the fold marking the next place that should be subsequently folded. Through this procedure one should obtain the illustration appearing in Figure 8:

44 Indeed, the insertion of recreational problems in mathematical texts or books in order to avoid the readers' or students' boredom was around long before the development of the genre of recreational mathematics. For example, the Rhind Papyrus (1650 BCE) or Babylonian clay tablets (1750 BCE) contained fanciful problems that led to quadratic equations. See Singmaster, 1994, p. 1568.

45 Unfortunately, we do not have much more information about Grandin.

46 "dont on fait un grand nombre de figures différentes". 
"by stretching this paper, and by opening the folds which are one upon another, we do any of the following shapes, one only needs to practice" ${ }^{47}$ (Ozanam, 1723, p. 432). The list of shapes contains thirtyfour diversified suggestions such as a carriage entrance, a square table, an umbrella, a fan or a salt cellar.

The description of the trick is quite brief (two pages) and no further explanations are provided to explain how to obtain the shapes mentioned above. Letters are used to designate the different parts of the sheet of paper, but no mathematical ideas (parallel lines, square basis, etc.) are present in these explanations.

Due to the popularity of Ozanam's Récréations mathématiques et physiques and its numerous translations, one can find exactly the same illustrations and list of folded shapes in Pablo Minguet's Engaños a ojos vistas (1733) and Giuseppe Alberti's I giochi numerici (1747). According to Sallas (2010, p. 126), this technique of folding a sheet of paper as a fan to create a three-dimensional object is now called "troublewit" in the world of origami, and can be dated back to 1675 in London. At this point, we would like to highlight the fact that this technique-and the section on cup and game-bag tricks-is not in the original edition of Ozanam's book. What this indicates is that the source of this technique was different: someone else who knew the troublewit

47 "En tirant sur ce papier, et en ouvrant les plis qui sont les uns sur les autres, on fait toutes les figures suivantes, il n'y a qu'à s'exercer”. 


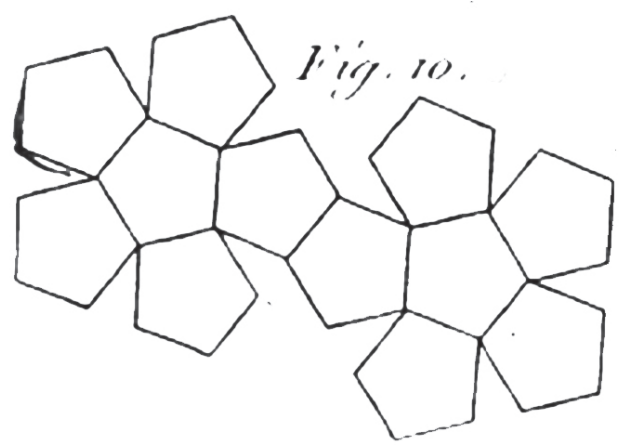

Figure 9. Dodecahedron's net (Guyot, 1799b, p. 24).

practice added it. But at this point it is not possible to trace back the source of inspiration which has led the editor to include these illustrations into Ozanam's republication. ${ }^{48}$

A few years later, in 1769, the French physicist and inventor Edmé-Gilles Guyot (1706-1786) published an extended version in four volumes of Ozanam's Récréations mathématiques et physiques, entitled Nouvelles récréations physiques et mathématiques. Guyot especially worked on the creation of lanterns in phantasmagoria in order to show his experiments in public and popularise science. ${ }^{49}$ Guyot's books were translated into English and German and circulated widely in Europe.

In the fourth edition of three volumes of Nouvelles récréations physiques et mathématiques (1799), the foreword mentions that new discoveries in electricity have been added, and that some amusements have been improved and simplified. Despite the presence of a section devoted to game-bag and cup tricks, there is no description nor illustration of a trick that proposes to fold a sheet of paper to obtain particular shapes, such as in 1723 Ozanam's edition. However, in the second volume of the 1799 edition, one finds the following problem (in the section devoted to geometry) about the "the way to draw and form with a single sheet of cardboard every different regular polyhedra" ${ }^{30}$ (Guyot, 1799b, p. 30), for example a dodecahedron (see Fig. 9). This echoes the well-known Dürerian

48 However, the similarities between the 27th trick in Ozanam's posthumous 1723 edition of Récréations mathématiques et physiques (Fig. 8) and the napkin-folding techniques of Harsdörffer's 1652 Vollständiges und von neuem vermehrtes Trincir-Buch (Fig. 7) are noticeable. This was a common practice during the 18th century in France for science education and popularisation.

50 "Manière de tracer et former d'une seule feuille de carton tous les différents polyhèdres réguliers". 
tradition of presenting polyhedra via their unfolded net, a tradition which was also present, as shown before, in Schwenter's and Harsdörffer's books.

More generally, the sections that follow the part on geometry in this second volume of the 1799 edition (on lighting, optics, perspective, catoptrics, dioptrics, etc.) did not appear in the other previous editions of Ozanam's Récréations. Knowing geometry and its properties is "essentially necessary" to perform the recreations with precision, and the foreword emphasises the fact that geometry is "intimately connected to every science and every art" (Foreword in Guyot, 1799a)..$^{51}$ One may wonder why the nets of polyhedra were not more present in previous editions of other recreational mathematics books. Indeed, drawing with perspective techniques-which was the second method Dürer and his followers used to represent polyhedra-was known in France, especially in painting, long before the end of the 18th century. It seems, however, that Dürer's nets of polyhedra were a relatively uncommon technique. This is attested by the lack of representations of nets of polyhedra in recreational mathematics before Guyot. Nevertheless, the aim of these recreations remains the same and is even made more explicit by the different authors in the Preface: "not only to learn and to entertain pleasantly, but also to show to the informed person that there is nothing occult in those kind of entertainments" (Guyot, 1799a, p. xv), ${ }^{52}$ because "the knowledge of principles and their applications are the only way to guide us and to prevent us from admiring things without understanding them" (Guyot, 1799a, p. xi). ${ }^{53}$ This vision reflects the Baconian conception of science, as explained in Section 5, a conception of scientific enquiry, which encouraged practice and experiment.

\section{Conclusion}

Paper folding, although being a small part of the recreational mathematics tradition in the 17 th and the 18 th centuries, nevertheless reflected how this tradition operated. This article did not attempt to give a full survey of the whole movement of recreational mathematics during these centuries, but it is clear that they were conceived as a way of communicating mathematical knowledge

\footnotetext{
51 "intimement liés avec toutes les sciences et tous les arts".

52 "non-seulement d'instruire et d'amuser agréablement, mais encore de faire connoître aux personnes prévenues, qu'il n'entre rien de surnaturel dans ces sortes d'amusemens".

53 "La connoissance des principes et leur application sont les seuls moyens qui puissent nous guider et nous empêcher d'admirer les choses sans les comprendre".
} 
to the literate classes of population (who could afford to purchase the books), and certainly not only for children. As Berns (1991, pp. xiii-xiv, xxvii) notes, the works of Schwenter and Harsdörffer already offered the opportunity of an independent study of sciences. Within this tradition, paper folding provided an implicit and explicit way of communicating geometrical knowledge. Implicitly, as the exercises that were inspired from napkin folding were not directly declared as aiming to teach geometrical knowledge concerning certain forms; explicitly, since the introduction of Dürer's methods into manuals of recreational mathematics had an obvious mathematical background-the construction of various polyhedra.

Recreational mathematics acted as practical activities presenting mathematical interest through entertainment. More specifically, paper folding involved a special type of practice- a tactile one, influenced by Dürer's nets and the activity of napkin folding, both of which were haptic. This is evident not only in the citation from Guyot's book which states that in these activities "there is nothing occult", but also in Harsdörffer's quote that refers to three types of knowledge: the symbolical-linguistic, the visual, and the haptic-tactile. The latter that goes hand in hand with the Baconian conception of science and experimentation is practised within every recreational mathematical book surveyed in this article, both in Germany and in France. Indeed, both the Baconian and, respectively, the Cartesian conceptions of the discovery of geometrical knowledge stress, as shown above, the tactile-haptic aspect of the crafts, with which one should experiment and through which geometrical laws may be discovered. This does not imply that the practices involved in these three types of knowledge were considered separate from each other. By contrast, they should have been practised together in order to obtain the "understanding" and "the knowledge of principles" that underlie the recreations. Indeed, neither in the section of L'escole parfaite des officiers de bouche which is concerned with folding, nor in the fourth edition of Nouvelles récréations physiques et mathématiques were there any illustrations on how to fold. On the one hand, one might suggest that the separation of these practices - the visual and the haptic_-prompted a slower dissemination of paper folding as an activity in the French recreational mathematics; on the other hand, the prominence of Dürer's methods in Germany certainly advanced the integration of paper folding within that tradition. Eventually, by the end of the 18th century, these practices of paper folding in recreational mathematics were more widespread when compared to the beginning of the 17 th century. This indicates the role, concerning both education and geometrical research, that this genre played in the dissemination of geometrical knowledge in these centuries. 


\section{References}

Bacon, F. (1960), The New Organon, ed. by H. A. Fulton, New York: Macmillan.

Barbin, E. (2007), 'Les Récréations: des mathématiques à la marge,' Pour la Science, February-March, pp. 22-25.

Berns, J. J. (1991), 'Einleitung,' in G. P. Harsdörffer, D. Schwenter (1636), Deliciae physico-mathematicae, oder mathematische und philosophische Erquickstunden, Reprint, ed. by J. J. Berns, Frankfurt am Main: Keip, pp. v-xiv.

de Bovelles, C. (1511), Geometrie en Françoys, Paris: Henri Estienne.

Braungart, G. (2011), 'Harsdörrfers Naturkunde,' in S. Keppler-Tasakz \& U. Kocher (eds.) Georg Philipp Harsdörffers Unıversalität, Berlin \& New York: de Gruyter, pp. 237-246.

Bruner, J. S. Oliver, R. S. \& Greenfield, P. M. (1971), Studien zur kognitiven Entwicklung, Stuttgart: Kohlhammer.

Cantor, M. (1891), 'Schwenter, Daniel,' in Allgemeine Deutsche Biographie, Historischen Kommission bei der Bayerischen Akademie der Wissenschaften, vol. 33, pp. 413-414.

Chabaud, G. (1994), Sciences en jeux: les "récreations mathématiques et physiques" aux XVIIème et XVIIIème siècles, $\mathrm{PhD}$ thesis, École des Hautes Études en Sciences Sociales, Paris.

Clemens, R. \& Graham, T. (2007), Introduction to Manuscript Studies, Ithaca: Cornell University Press.

Conner, C. D. (2005), A People's History of Science: Miners, Midwives, and "Low Mechanicks", New York: Nation Books.

Descartes, R. (1988), Descartes: Selected Philosophical Writings, transl. by J. Cottingham $\&$ R. Stoothoff, Cambridge: Cambridge University Press.

Dürer, A. (1977 [1525]), The Painter's Manual, transl. with comments by W. L. Strauss, New York: Abaris Books.

de Fontenelle, B. (1719), 'Éloge de M. Ozanam,' Histoire de l'Académie Royale des Sciences, pp. 86-92.

Friedman, M. (2018), A History of Folding in Mathematics: Mathematizing the Margins, Basel: Birkhäuser.

Fröbel, F. (1874), Gesammelte pädagogische Schriften, vol. 2, ed. by W. Lange, Berlin: Enslin.

Gerstl, D., ed. (2005), Georg Philipp Harsdörffer und die Künste, Nürnberg: H. Carl.

Giegher, M. (1629), Li tre trattati, Padova: Guareschi.

Gloning, T. (2003), Organisation und Entwicklung historischer Wortschätze, Tübingen: Max Niemeyer. 
Guyot, E.-G. (1799a), Nouvelles récréations physiques et mathématiques, contenant ce qui a été imaginé de plus curieux dans ce genre et qui se découvre journellement, vol. 1, Paris: Librairie rue $S$. André-des-Arcs.

(1799b), Nouvelles récréations physiques et mathématiques, contenant ce qui a été imaginé de plus curieux dans ce genre et qui se découvre journellement, vol. 2, Paris: À la librairie rue S. André-des-Arcs, nº 46.

Harsdörrfer, G. P. (1651), Deliciae physico-mathematicae, oder mathematische und philosophische Erquickstunden Zweyter Theil, Nürnberg: Dümler.

— (1652), Vollständiges und von neuem vermehrtes Trincir-Buch, Nürnberg: Fürst.

(1653), Deliciae physico-mathematicae, oder mathematische und philosophische Erquickstunden Dritter Theil, Nürnberg: Endters.

Heeffer, A. (2004), Récréations Mathématiques (1624) A Study on its Authorship, Sources and Influence, Ghent: Ghent University.

Heerwart, E. (1894), Course of Paper Plaiting or Mat Weaving, London: Charles \& Dible.

Heinecke, B. (2008), 'The Poet And The Philosopher: Francis Bacon And Georg Philipp Harsdörffer,' in C. Zittel, G. Engel, R. Nanni \& N. Karafyllis (eds.) Philosophies of Technology: Francis Bacon and His Contemporaries, Leiden: Brill, pp. 373-410. https://doi.org/10.1163/ej.9789004170506.i-582.103

(2011), 'Naturphilosophie bei Georg Philipp Harsdörffer,' in S. Keppler-Tasakz \& U. Kocher (eds.) Georg Philipp Harsdörffers Unwversalität, Berlin \& New York: de Gruyter, pp. 247-278. https://doi.org/10.1515/9783110251081.247

Heuer, C. P. (2011), 'Dürer's Folds,' RES: Anthropology and Aesthetics, vol. 59/60, pp. 249-265.

Klett, A. (1677), Neues Trenchier- und Plicatur-Büchlein, Nürnberg: Loschge.

La Varenne, P. F. (1651), Le cuisinier françois enseignant la manière de bien apprêter et assaisonner toutes sortes de viandes grasses et maigres, legumes et patisseries et autres mets qui se servent sur les tables tant des Grands que des particuliers, Paris: David.

Karr Schmidt, S. (2006), Art-A User's Guide: Interactive and Sculptural Printmaking in the Renaissance, PhD dissertation, Yale University.

Lachapelle, S. (2015), Conjuring Science. A History of Scientific Entertainment and Stage Magic in Modern France, New York: Palgrave Macmillan.

Ozanam, J. (1723), Récréations mathématiques et physiques, où l'on traite des phosphores naturels et artificiels, et des lampes perpetuelles. Dissertation physique et chimique, avec l'explication des tours de gibecière, de gobelets et autres récréatifs et divertissants, vol. 4, Paris: Jombert.

Peiffer, J. (2004), 'Projections Embodied in Technical Drawings: Dürer and His Followers,' in L. Wolfgang (ed.) Picturing Machines, Cambridge, MA: MIT Press, pp. 245-275.

Peter, P. (2008), Kulturgeschichte der deutschen Küche, München: C. H. Beck. 
Ribou, J. (1662), L'escole parfaite des officiers de bouche; contenant Le Vrai Maitre d'Hôtel, Le grand Ecuyer-Tranchant, Le Sommelier Royal, Le Confiturier Royal, Le Cuisiner Royal et le Pâtissier Royal, Paris: David / Ribou.

Richter, F. (1995), Die Ästhetik geometrischer Körper in der Renaissance, Stuttgart: Gerd Hatje.

Romano, A. (1995), 'Du Collège romain à La Flèche : problèmes et enjeux de la diffusion des mathématiques dans les collèges jésuites (1580-1620), in Mélanges de l'École française de Rome. Italie et Méditerranée, vol. 107, no. 2, pp. 575-627. https://doi.org/10.3406/mefr.1995.4397

Sallas, J. (2010), Gefaltete Schönheit. Die Kunst des Serviettenbrechens, Wien: Freiburg i. Breisgau.

Schaaf, W. (1963), Recreational Mathematics A Guide to the Literature, Washington, DC: The National Council of Teachers of Mathematics, INC.

Schwenter, D. (1636), Deliciae physico-mathematicae, oder mathematische und philosophische Erquickstunden, Nürnberg: Dümler.

Singmaster, D. (1994), 'Recreational Mathematics,' in I. Grattan-Guiness (ed.) Companion Encyclopedia of the History and Philosophy of Mathematical Sciences, vol. 2, London and New York: Routledge. https://doi.org/10.1201/b10573-9

- (2008), 'De viribus quantitatis by Luca Pacioli: The First Recreational Mathematics Book,' in E. Demaine et al. (eds.) A Lifetime of Puzzles, Wellesley: A.K. Peters, Ltd, pp. 77-122.

Staigmüller, H. C. O. (1891), Dürer als Mathematiker, Stuttgart: K. Hofbuchdrukker.

Steck, M. (1948), Dürers Gestaltlehre: Der Mathematik und der Bildenden Kunste, Halle: Max Niemeyer.

Wurst, K. A. (2004), 'The utility of play or the enchantment of instruction and cultural encounters: Georg Philipp Harsdörffer's Frauenzimmer Gesprächspiele,' Daphnis, vol. 33, no. 1-2, pp. 285-302.

Michael Friedman is a research associate at the Cluster of Excellence Bild Wissen Gestaltung, an interdisciplinary laboratory of the Humboldt University, Berlin. He holds a doctorate in Mathematics from Bar-Ilan University, Israel, and a MA in Philosophy from Tel Aviv University. The focus of his research is the history of the mathematisation of folding between the 16th century and the 21st century, as well as the history of visualisation techniques of mathematical objects during the 2oth century. His recent publications include Psychoanalysis: Topological Perspectives (Bielefeld: transcript, 2016, co-edited with Samo Tomšič); Martin Heidegger: Die Falte der Sprache (Vienna: Turia + Kant, 2017, co-edited with Angelika Seppi); and On the History of Folding in Mathematics: A Mathematization of the Margins (Basel: Birkhäuser, 2018). 
Lisa Rougetet is a senior lecturer at the Centre François Viète, a history of science and technology laboratory of the Université de Bretagne Occidentale in Brest, France. She defended her PhD in History of Mathematics in 2014 on the history of combinatorial game theory. Her research interests include the study of the history of recreational mathematics, and the history of the first combinatorial game playing machines. She is also concerned with connections between board games, computer algorithms and history, and their application in mathematics education. Her article 'A Prehistory of Nim' was selected for the collection Best Writing on Mathematics 2015, Princeton University Press. 